\title{
FOOD COMPOSITION AND PREY SELECTION OF COD, GADUS MORHUA (ACTINOPTERYGII: GADIFORMES: GADIDAE), IN THE SOUTHERN BALTIC SEA
}

\author{
Marzenna E. PACHUR and Jan HORBOWY*
}

\author{
Department of Fishery Resources, National Marine Fisheries Research Institute, Gdynia, Poland
}

Pachur M.E., Horbowy J. 2013. Food composition and prey selection of cod, Gadus morhua (Actinopterygii: Gadiformes: Gadidae), in the southern Baltic Sea. Acta Ichthyol. Piscat. 43 (2): 109-118.

Background. At the end of 1980s, ecological regime shifts occurred in the Baltic. Since, the Baltic fish assemblage has been dominated by sprats, whereas before cod was the dominant fish species. The majority of previous food studies refer to the period before the shift. This raises the question, how changes in the Baltic ecosystem have affected the diet of cod. The aim of the presently reported study was to identify the differences in the food composition of cod depending on the area, depth, season, and the cod size and compare it with the findings from the 1970 s and 1980s.

Materials and methods. Food composition and selection of prey size for Baltic cod was evaluated by examining the stomach contents of 556 adult cod, collected in 2006 and 2007. Fish stomachs were sampled from research catches within the Polish Exclusive Economic Zone.

Results. The main component of the cod diet were the clupeids, constituting more than $67 \%$ of the total weight of the food recovered from the specimens studied. Other fishes in the diet represented Gobiidae, Ammodytidae, as well as young cod. The dominant invertebrate in the diet was the isopod Saduria entomon which accounted for $13 \%$ of the diet by weight. The weight proportion of larger fish, such as herring, Clupea harengus (L.), and cod, increased with the cod size, while the proportion of small- and medium-sized fish (sprats, gobies) decreased. The food composition of cod varied seasonally. The weight proportion of European sprat, Sprattus sprattus (L.), was much higher in winter $(55 \%)$ than in fall $(27 \%)$, while the proportion of cod in the diet was higher in the fall $(10 \%)$ than in winter $(4 \%)$. The proportion of sprat in the diet increased with depth, while that of Ammodytidae and Gobiidae showed a decreasing trend. At depths greater than $40 \mathrm{~m}$, the proportion of invertebrates in cod stomachs decreased. This study demonstrated a significant area effect for sprat; year effect for sprat and Saduria entomon; a seasonal effect for young cod and S. entomon; and a depth effect for sprat, young cod, and S. entomon. The occurrences of herring and small cod increased in the stomach as the predator increased, while no significant relation was found for sprat and S. entomon. The data collected do not indicate that cod select a specific size of sprat or herring, though cod were found to use size selection for S. entomon and juvenile cod.

Conclusion. The food composition of cod has undergone certain changes compared to results of Załachowski (1977, 1985), which covered the 1970s and 1980s. Currently, the proportion of clupeids in the food is approximately $67 \%$ (in weight), while during the $1977-1982$ it was in the range of $25 \%-50 \%$ depending on cod length. In 2006 and 2007 sprat was the main cod diet component rather than herring.

Keywords: cod, Baltic, feeding, prey size, cannibalism

\section{INTRODUCTION}

Studies of fish diet are important for two reasons. Firstly, they allow us to learn about the interactions among particular species in a given environment, thus making substantial contributions to the knowledge of that ecosystem. Secondly, the results of these studies can be used in mathematical models to describe stock dynamics. In the late 1970s and early 1980s, researchers focused their attention on the impact that interactions among species can have on stock dynamics. It was recognised that intensive exploitation of resources can cause disturbances to the ecosystem balance, which can result in changes in species interactions. Omitting information on species interactions can result in gross errors in stock estimation (Horbowy 1996). Consequently, several multispecies models were developed that take trophic interactions into consideration, and attempts were made to employ these models in resource management. One approach that was often applied was the multi-species virtual population model (Helgason and Gislason 1979). Due

\footnotetext{
* Correspondence: Dr Jan Horbowy, Zakład Zasobów Rybackich, Morski Instytut Rybacki - Państwowy Instytut Badawczy, ul. Kołłataja 1, 81-332 Gdynia, Poland, phone: +48 587-356-267, fax: +48 587-356-110, e-mail: horbowy@mir.gdynia.pl (M. Pachur: pachur@mir.gdynia.pl).
} 
to its relatively simple trophic structure, the Baltic Sea is a good study area for the application of multi-species models, and it is standard practice in stock assessment to take the clupeid mortality caused by cod predation into consideration (Anonymous 2012).

Studies of the food composition of cod from the southern Baltic were conducted as early as the 1950s and 1960s (Reimann 1955, Strzyżewska 1959, 1962, Chrzan 1962). Załachowski (1977, 1985, 1986, 1992) presented an evaluation of the quantity, composition, and biomass of the food consumed by the cod population in Polish waters within 1972-1974, 1977-1982, and 1986-1989. Arntz (1977) studied the food of adult cod in the western Baltic. Uzars (1985) and Uzars and Plikshs (2000) investigated the issue of feeding, and analysed cannibalism among Baltic cod from subdivisions 25, 26, and 28 based on material from 1963-1990. Neuenfeldt and Beyer (2003, 2006) draw attention to environmentally driven cod-prey overlap and its effect on food composition in the Baltic.

At the end of 1980s, ecological regime shifts had been observed in the Baltic (Alheit et al. 2005). The Baltic ecosystem is currently dominated by sprats, which is in contrast to the 1980s when the dominant species was cod. The majority of food studies refer to the period when cod was the dominant species, and this raises the question of how changes in the Baltic ecosystem have affected the cod diet. The aim of the presently reported study was to identify the differences in the food composition of cod depending on the area, depth, season and the cod size and to compare the today's cod diet with that of the 1970s and 1980s.

\section{MATERIALS AND METHODS}

The samples used in this study (556 cod stomachs) were collected between February 2006 and November 2007 from fishing grounds in ICES subdivisions 25 and 26 within the Polish Exclusive Economic Zone (EEZ) (Fig. 1, Table 1). The samples were collected from scientific catches made from the R/V Baltica deploying a tv3 bottom trawl for $0.5 \mathrm{~h}$.

The fish sampled for their stomach contents were measured to the nearest $\mathrm{cm}$ (total length defined as the length from the tip of the upper jaw to the tip of the caudal fin, TL) and weighed to the nearest $\mathrm{g}$. The stomachs were labelled, placed in buckets, and preserved in 70\% alcohol. Only the anterior part of the alimentary tract (the oesophagus and stomach) was analysed. The contents of the alimentary tracts were weighed to the nearest $0.1 \mathrm{~g}$. The food items found in the stomachs were sorted, counted, weighed, and identified to the lowest taxonomic unit. Proportion of the total weight and frequency of occurrence of each of the food components were determined. For a presentation of the overall food composition, the frequency and weight indices were calculated and shown in 'Costello plot' (Costello 1990). The weight of digested unrecognisable prey, which made up just a small percentage of the total food consumed, has not been analysed.

All of the fish occurring in the stomach contents were measured to the nearest $0.5 \mathrm{~cm}$ determining either total length (TL) or standard length (SL, defined as the length from the tip the upper jaw to caudal fin base). In case of a broken tails, total length was determined from the TL-SL relation. The weight of consumed fish was meas-

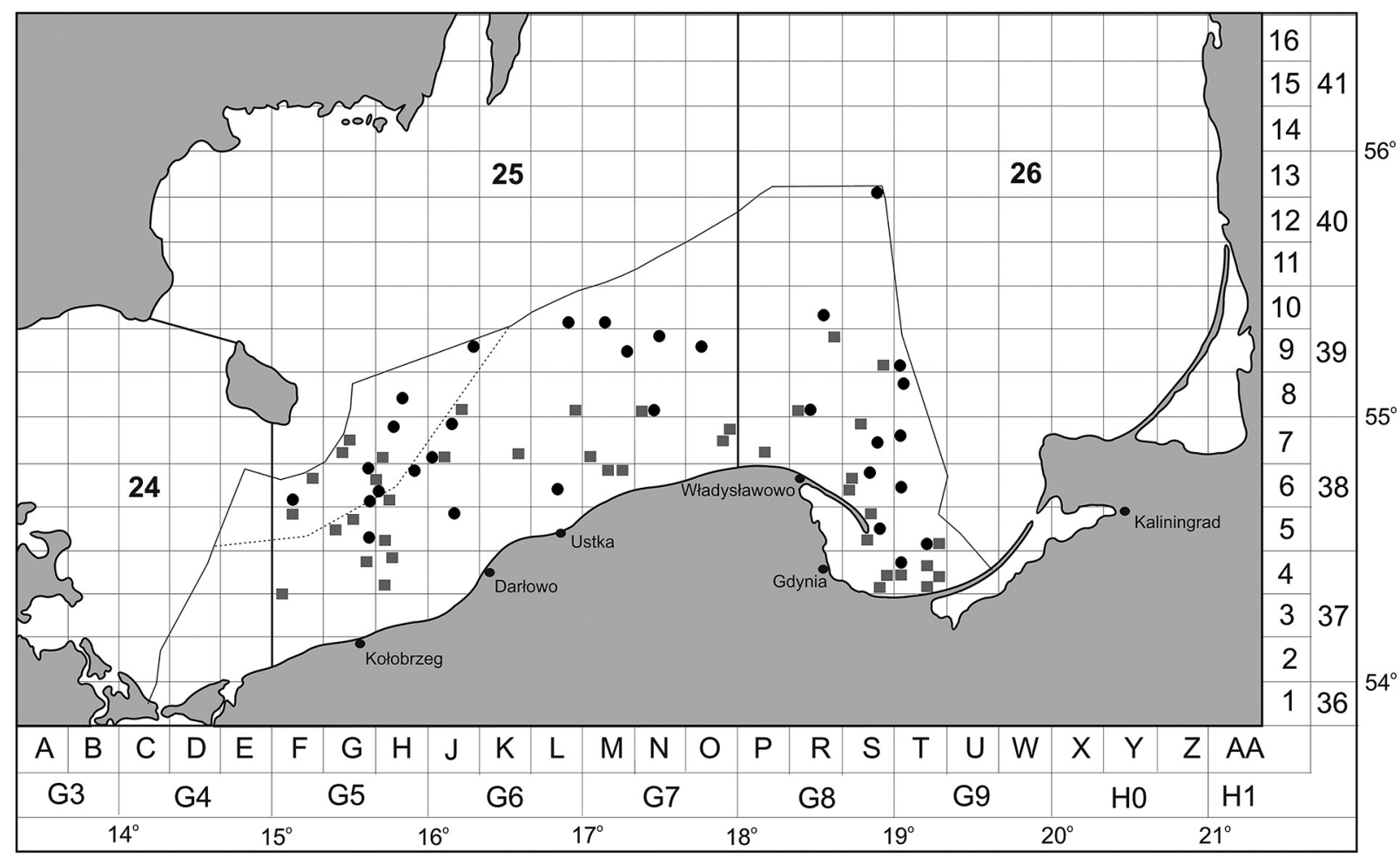

Fig. 1. Distribution of sampling sites in 2006 and $2007(\bullet 2006, \boldsymbol{\bullet}$ 2007) in the Baltic (borders of the Polish Exclusive Economic Zone marked by a thin solid line) 
ured from the weight-length relation, or from the relation between the otolith size and fish size (Härkönen 1986). The lengths of Saduria entomon (Isopoda) were determined to the nearest $0.1 \mathrm{~cm}$, and the weight of individual, undigested $S$. entomon was determined to the nearest $0.01 \mathrm{~g}$. The weight of all $S$. entomon in cod stomachs was determined multiplying the mean individual weight of the undigested individuals by the number of all individuals of $S$. entomon found in the stomachs. Prey size selection was analysed by relating the mean length of prey (TL) of a given species to the mean length of cod.

A precise taxonomic identification of fish prey to the species level was sometimes difficult because of digestion, thus it was necessary to group specimens as Clupeidae gen. spp. or Actinopterygii gen. spp. Prey items representing the fish families Ammodytidae and Gobiidae (either identified to the species level or not identified) were pooled because they constituted a small share of the samples.

The total stomach contents in the samples were extrapolated to the whole population by weighing the stomach contents of the different length classes of cod by the mean proportion of a given length class in the population. The length distribution of the population was determined based on length samples collected during research cruises aboard the R/V Baltica (Fig. 2).

The generalized linear models (GLM; Nelder and Wedderburn 1972) were used to test for statistical effects of selected factors (year, season, depth, area) and a covariate (predator length) on stomach contents, expressed as occurrences of a given food item (fraction of fish with that item), $p$. The following model was used:

$\mathrm{G}(p)=$ year + season + area + depth + length,

where: the year is 2006 or 2007, the season is winter (February) or fall (November), the area is Subdivision 25 or Subdivision 26, depth is depth $<60 \mathrm{~m}$ or depth $>=60 \mathrm{~m}$, and cod length was expressed in $10 \mathrm{~cm}$ intervals. $\mathrm{G}$ is the link function and in the analysis the logit link was used and the distribution of the response was assumed to be binomial. GLMs were applied to separate analyses of the occurrences of sprat, herring, young cod, and S. entomon in cod stomachs. Depth was constrained to two levels only to provide a better coverage of the strata.

In addition, an analysis of variance was used to compare cod food composition at length between years. A Shapiro-Wilk test was used to test the normality of the distribution for ANOVA tests.

\section{RESULTS}

Food composition. Clupeids dominated in the diet of cod and together with unidentified components they comprised over $67 \%$ of the total food weight (Fig. 3, Table 2). The weight proportion of sprat in the diet was nearly fourfold higher than that of herring, Clupea harengus L. Other fish found in the diet-Gobiidae, Ammodytidae, and cod-made up between $2 \%$ and $5 \%$ of the total prey weight. Invertebrates constituted approximately $20 \%$ of the food mass of which the isopod Saduria entomon made up $13 \%$. The food components with the highest frequency
Table 1

Number of cod, Gadus morhua, stomachs collected by depth and subdivision

\begin{tabular}{lcccc}
\hline Season & $\begin{array}{c}\text { ICES } \\
\text { subdivision }\end{array}$ & Depth [m] & $\begin{array}{c}\text { No. of } \\
\text { stomachs }\end{array}$ & Total \\
\hline February 2006 & 25 & $53-75$ & 83 & 150 \\
& 26 & $60-102$ & 67 & \\
November 2006 & 25 & $27-91$ & 88 & 126 \\
& 26 & $30-99$ & 38 & \\
February 2007 & 25 & $20-77$ & 81 & 147 \\
November 2007 & 26 & $25-99$ & 66 & \\
& 26 & $28-75$ & 66 & 133 \\
\hline
\end{tabular}

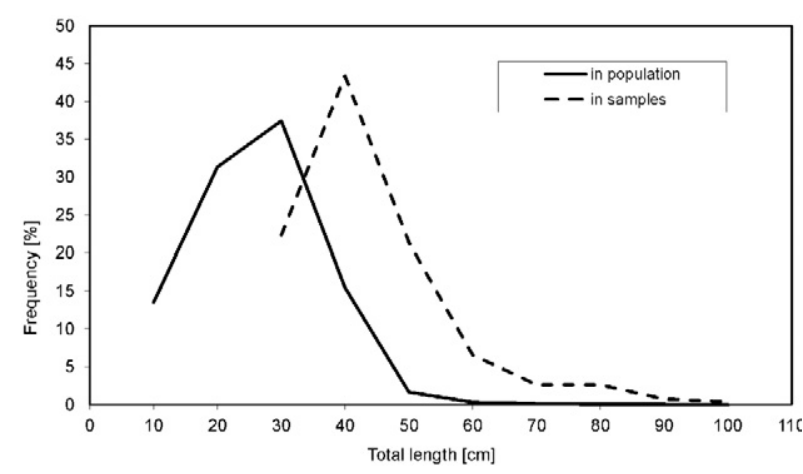

Fig. 2. Length distribution (10 cm length classes) of cod, Gadus morhua, in the population (from four bottom surveys in winter and fall 2006 and 2007, $n=30$ 661) and of cod studied in the diet analysis $(n=556)$

of occurrence were sprat (51\%) and S. entomon (44\%). Cod fed regularly on fish belonging to the family Gobiidae, Mysidacea, as well as on shrimp Crangon crangon $(29 \%-35 \%)$. The occasional food items of cod were: polychaetes Bylgides sarsi, amphipods Pontoporeia sp., and herring. Cod occurred in only $2.5 \%$ of the fish stomachs examined.

The confirmed Gobiidae were mostly fish of the genus Pomatoshistus and in a few cases round gobies, Neogobius melanostomus (Pallas, 1814), were also found. Among the Ammodytidae identified were small sandeel, Ammodytes tobianus L. and great sandeel, Hyperoplus lanceolatus (Le Sauvage, 1824) (known also as sand lance), but in many cases these fish were excessively digested, which made species identification impossible. In addition to the more commonly occurring species described above, the rare findings were: European flounder, Platichthys flesus (L.); fourbeard rockling, Enchelyopus cimbrius (Linnaeus, 1766); three-spined stickleback, Gasterosteus aculeatus L.; garfish, Belone belone (Linnaeus, 1761); eelpout, Zoarces viviparous (L.); and European anchovy, Engraulis encrasicholus (L.).

We observed also less common invertebrates such as: Gammarus sp., polychaetes Nereis diversicolor, Diastylis rathkei, Corophium volutator, Hyperia galba, and 
Palaemon adspersus, along with individual Baltic clams, Macoma balthica, or long-neck clams, Mya arenaria. Two Mysidacea species found were identified as Neomysis integer and Mysis mixta. The former of was more abundant in the stomachs of cod caught in shallower waters.
The stomachs of fish longer than $80 \mathrm{~cm}$ contained large cod, flounder, fourbeard rockling. Together, these three fish species constituted a total of $72 \%$ of the food weight. Among them the most important was cod (40\%). The remainder of the food consisted of clupeids.

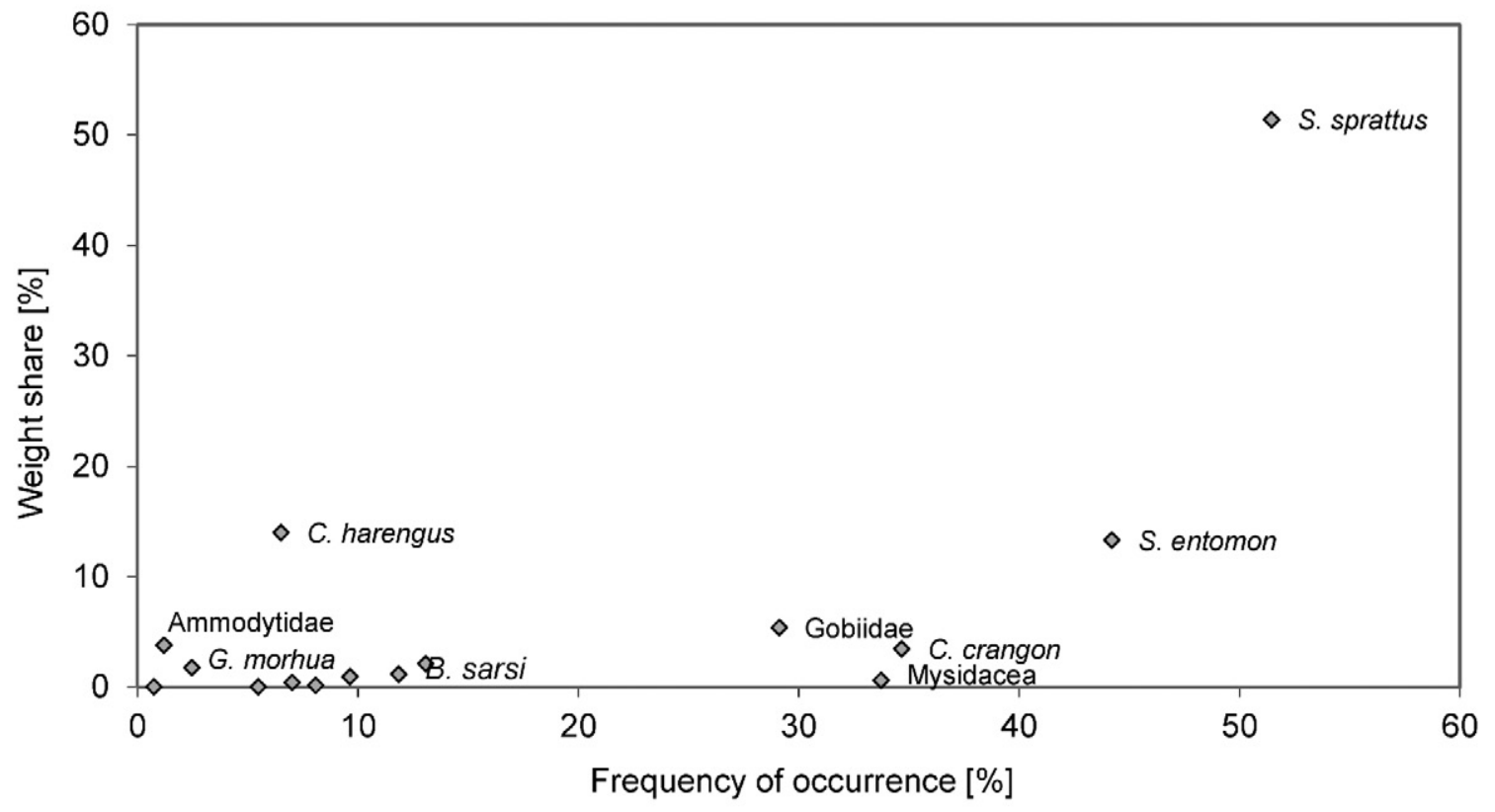

Fig. 3. Costello-plot (frequency of occurrence and weight of prey items) in the studied population of cod, Gadus morhua (data recalculated on cod population)

Food composition of cod, Gadus morhua (data recalculated on cod population)

\begin{tabular}{|c|c|c|c|c|c|}
\hline Prey category & Taxonomic group & Frequency [\%] & Weight $[\%]$ & Subdivision 25 & Subdivision 26 \\
\hline Bylgides sarsi & Polychaeta & 11.9 & 1.2 & 0.3 & 2.3 \\
\hline Nereis diversicolor & & 5.5 & $\sim 0$ & 0.0 & 0.0 \\
\hline Mysidacea gen spp. & Crustacea & 33.8 & 0.6 & 0.6 & 0.6 \\
\hline Pontoporeia sp. & & 9.7 & 0.9 & 1.6 & 0.0 \\
\hline Gammarus sp & & 8.1 & 0.2 & 0.3 & 0.0 \\
\hline Saduria entomon & & 44.2 & 13.3 & 16.5 & 8.9 \\
\hline Crangon crangon & & 34.7 & 3.4 & 4.8 & 1.5 \\
\hline Mytilus sp. & Bivalvia & 0.7 & $\sim 0$ & 0.0 & 0.0 \\
\hline Sprattus sprattus & Actinopterygii & 51.5 & 51.4 & 38.8 & 68.8 \\
\hline Clupea harengus & & 6.5 & 14 & 16.8 & 10.2 \\
\hline Clupeidae gen. spp. & & 13.1 & 2.1 & 1.6 & 2.9 \\
\hline Ammodytidae gen. spp. & & 1.2 & 3.8 & 6.5 & 0.0 \\
\hline Gobiidae gen. spp. & & 29.1 & 5.4 & 6.7 & 3.6 \\
\hline Gadus morhua & & 2.5 & 1.7 & 2.8 & 0.3 \\
\hline Actinopterygii gen. spp. & & 7 & 0.4 & 0.4 & 0.5 \\
\hline Platichthys flesus & & 1.2 & 0.2 & 0.2 & 0.3 \\
\hline Belone belone & & 0.3 & 1.2 & 2.2 & 0.0 \\
\hline Enchelyopus cimbrius & & 0.1 & 0.1 & 0.1 & 0.0 \\
\hline Other fishes & & 2.2 & 0.0 & 0.0 & 0.1 \\
\hline
\end{tabular}

"Actinopterygii gen. spp." were fish undetermined; "Other fishes" include rarely occurring, determined fish (Gasterosteus aculeatus, Zoarces viviparous, and Engraulis encrasicholus); Data for ICES subdivisions are given by weight \%. 
Cod cannibalism expressed as a frequency of occurrence was $5 \%$. Cannibalism was observed in 29 stomachs, and it was observed more often in the winter $(5 \%)$ than in the fall (4\%). The smallest cod cannibal was $39 \mathrm{~cm}$ in length. In about $30 \%$ of the cases noted, the cod consumed were larger than $20 \mathrm{~cm}$. The largest cod consumed was about $40 \mathrm{~cm}$ and its weight was $16 \%$ of the predator's weight. The young of the year cod were eaten mostly in the winter.

Statistical analysis of occurrences of prey species. A significant year effect was observed for the frequency of occurrences of sprat $(P<0.001)$ and Saduria entomon $(P<0.001)$; sprat occurred more frequently in 2007 while $S$. entomon occurred more frequently in 2006. A seasonal effect was significant for young $\operatorname{cod}(P<0.03)$ and $S$. entomon $(P<0.001)$. Young cod occurred more frequently in the winter, while $S$. entomon was observed more frequently in the fall.

The effect of subdivision was significant $(P<0.02)$ only in the case of sprat, and sprat occurred more often in stomachs collected in Subdivision 26 than in Subdivision 25. Depth stratum was a significant factor for sprat $(P<0.002)$, young cod $(P<0.004)$, and Saduria entomon $(P<0.001)$, while it was not significant for herring $(P<0.2)$. Sprat occurred more frequently in cod stomachs collected from deeper waters $(\geq 60 \mathrm{~m})$, while $S$. entomon and young cod occurred more frequently in cod sampled from shallower waters $(<60 \mathrm{~m})$.

The length of predator significantly influenced the frequency of occurrence of herring $(P<0.001)$ and young $\operatorname{cod}(P<0.001)$ in predators' stomachs.

The proportion of deviance (the GLM measure of data variability, similar to variance for models with normal errors) explained by significant factors and the co-variate was small for the prey items considered and ranged from 19\% for sprat and herring to $30 \%$ for young cod and S. entomon.

Food composition as dependent on cod length. The food composition of cod varied depending on the size of cod analysed (Fig. 4). The two-year mean of sprat in the food weight was high in the $30-50 \mathrm{~cm}$ length class $(30 \%-50 \%)$, but declined sharply to $20 \%$ in cod from the $80 \mathrm{~cm}$ length class.

The proportion of herring increased from just a few percent in the food of the $30-40 \mathrm{~cm}$ length class cod to over $20 \%$ for $80 \mathrm{~cm}$ cod. Similarly, the proportion of cod in the food of the $40 \mathrm{~cm}$ cod was marginal, while in the 60-80 cm length classes it increased, on average, from $10 \%$ to $30 \%$. Consistent with these findings, cod length was found to be significant in the GLM examining the frequency of occurrence of herring and young cod in cod food. The mean proportion by weight of Saduria entomon in the cod diet did not exhibit a clear trend with cod length: it declined in the $20-50 \mathrm{~cm}$ length classes from approximately $50 \%$ to $15 \%$, but increased again in the $60-80 \mathrm{~cm}$ classes to approximately $20 \%-30 \%$. The proportion of herring and juvenile cod at a given cod length did not differ much in 2006 and 2007 and the difference was not significant $(P=0.42$ and $P=0.17$, respectively). However, the proportions of sprat and $S$. entomon differed signifi- cantly in the two years $(P<0.007$ and $P<0.001$, respectively), being consistent with differences in the frequency of occurrence as analysed by a GLM. In 2006, the proportion of sprat was lower than that of $S$. entomon. One year later, there were more sprat than $S$. entomon, with a clear downward trend in the proportions of these two food components with increasing cod length for bigger cods.

The proportion by weight of Gobiidae in the diet of cod decreased with increasing cod length (Fig. 5), while the proportion of Ammodytidae varied. In the $60 \mathrm{~cm}$ length class, there was a higher proportion by weight of fish from the "other" group comprised of rarely consumed fish such as fourbeard rockling, eelpout, flounder, and anchovy. The weight of small invertebrates such as Mysidacea, Gammarus sp., Pontoporeia sp., Crangon crangon, and Bylgides sarsi declined in the diet of larger cod. The frequency of occurrence of food organisms decreased with increasing cod size for Gobiidae and all invertebrates, except for Bylgides sarsi, which increased in frequency (Fig. 5). Generally, the diversity of invertebrates in the diet decreased with cod size.

Food composition by subdivision, season and depth. In Subdivision 26, sprat made up $69 \%$ of the weight of the food consumed, while in Subdivision 25 sprat made up $39 \%$ of the diet by weight (Table 2), which was consistent with the significantly higher frequency of occurrences of

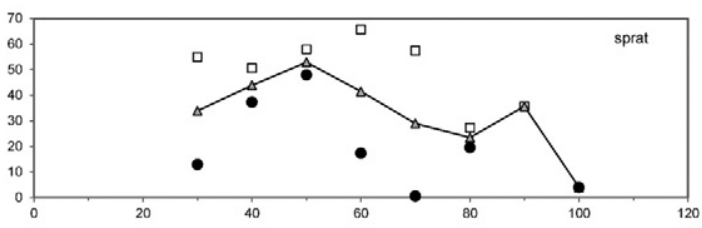

-
5
5
5
0
0
0
3
$=$
-
0
5
5
5
0
$>0$
0
0
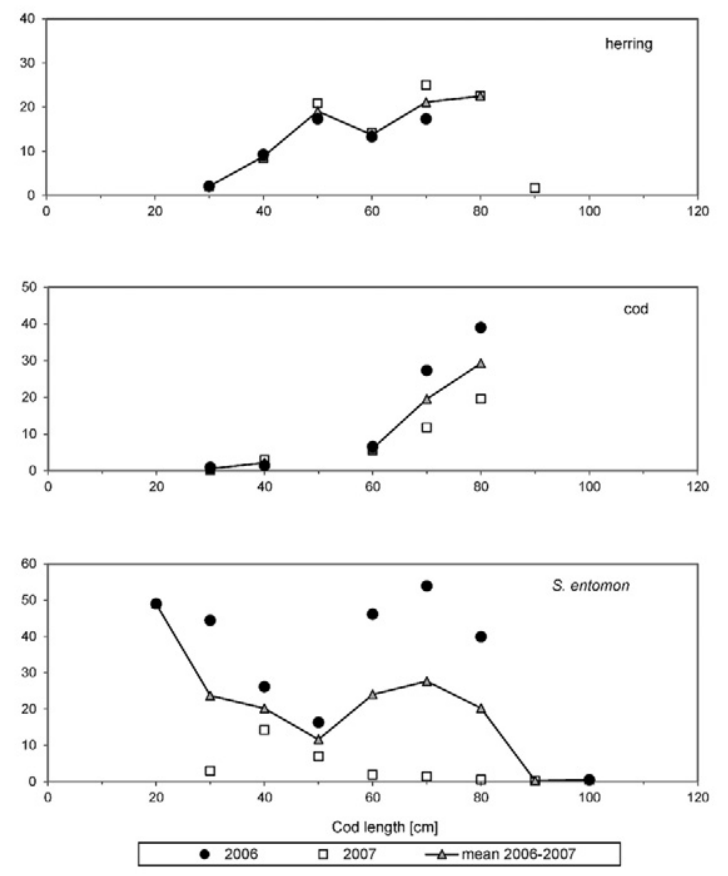

Fig. 4. Weight proportion of the main components of cod, Gadus morhua, diet (sprat, herring, cod, S. entomon) as dependent on predator length groups 
sprat in cod stomachs collected in Subdivision 26. The proportion of other food components was generally lower in Subdivision 26 than in Subdivision 25.

The proportion by weight of sprat in cod food was much higher in winter $(55 \%)$ than in fall $(27 \%)$. The proportion of cod in the diet was $10 \%$ in the fall and $4 \%$ in the winter. Moreover, the proportion of Ammodytidae was markedly higher in the fall than in the winter of 2007. Proportions of herring and Saduria entomon were generally similar in both seasons, except for large proportions of S. entomon in the fall of 2006 (Fig. 6).

The proportion of sprat by weight in the diet largely increased at depths exceeding $60 \mathrm{~m}$ (Fig. 7). The proportion of herring was the highest at depths between 40 to 60 $\mathrm{m}$. As depth increased, the proportions of Gobiidae declined. Fish of the family Ammodytidae occur only in the coastal zone, primarily at depths between 15 to $20 \mathrm{~m}$. The proportion of Saduria entomon increased down to the depth of $60 \mathrm{~m}$, and then decreased considerably in deeper waters (a decrease from $23 \%$ to $7 \%$ of the total weight). The greatest species diversity of other invertebrates occurred in stomachs sampled at depths of $40 \mathrm{~m}$. Below this depth, the proportion of Mysidacea, Gammarus sp., Pontoporeia sp., and Crangon crangon decreased. Among the Mysidacea, at depths down to $40 \mathrm{~m}$, there was a several-fold numerical advantage of Neomysis integer over Mysis mixta, while to depths of $20 \mathrm{~m}$, only the former genus was observed. Below the depth of $40 \mathrm{~m}$, the quantity of Neomysis integer decreased in favour of Mysis mixta. Cod food selectivity. The data collected do not indicate size selection of sprat or herring by cod (Fig. 8) and the correlation coefficients for the dependence of herring or sprat length on cod length are close to zero. There is a clear size selection for Saduria entomon and juvenile $\operatorname{cod}(P<0.001$ in both cases; Fig. 8). The correlation coefficients $(R)$ of these dependencies were 0.51 and 0.84 , respectively. With $S$. entomon, the correlation between the isopod length and the cod length increased with sampling depth, and for samples from depths of $40 \mathrm{~m}, 60 \mathrm{~m}$, $80 \mathrm{~m}$, and $100 \mathrm{~m}$ the values for the correlations were 0.47 , $0.49,0.78$, and 0.84 , respectively.

\section{DISCUSSION}

The food habits of cod were found to change with season, area, and depth. However, these factors affected stomach contents of cod in different ways for specific prey items. For example, the area effect was significant only for sprat, the depth effect was significant for sprat, young cod, and Saduria entomon, the season effect was significant for young cod, and S. entomon. The food composition of cod changed markedly with cod size; larger cod had higher weight share of fish than the smaller individuals. The size selection was observed for such prey items as young cod and $S$. entomon but has not been significant for sprat and herring.

The food composition of cod has undergone certain changes compared to results of Załachowski (1977, 1985), which covered the 1970s and 1980s. Currently, the proportion of clupeids in the food is approximately $67 \%$ (in weight), while during the 1977-1982 it was within the range of $25 \%-50 \%$, depending on cod length. Sprat now dominates the cod diet rather than herring. The proportion

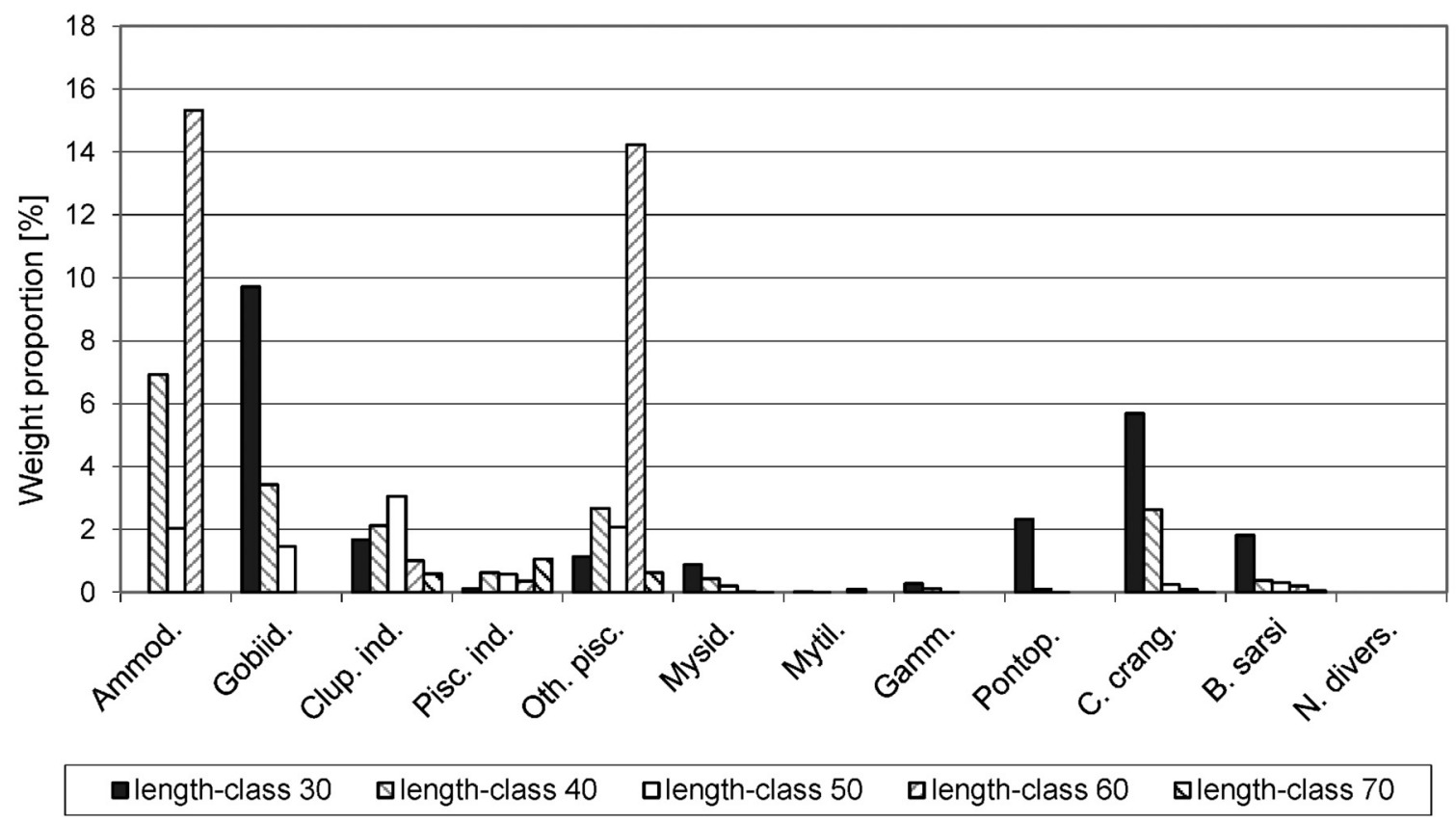

Fig. 5. The weight proportion and frequency of occurrence of the less important components of cod, Gadus morhua, diet by predator length groups; Ammod. = Ammodytidae, Gobiid. = Gobiidae, Clup. ind. = Clupeidae gen. spp., Pisc. ind. = Actinopterygii gen. spp., Oth. pisc. = Other fishes (identified), Mysid. = Mysidacea gen. spp., Mytil. = Mytilus sp., Gamm. = Gammarus sp., Pontop. = Pontoporeia sp., C. crang. = Crangon crangon, B. sarsi = Bylgides sarsi, N. divers. $=$ Nereis diversicolor 
of herring in the diet studied by Załachowski (1985) was similar to that in the presently reported study, while the proportion of sprat was very low, within the range of $7 \%-12 \%$ in various length classes. In this study, sprat comprised between $20 \%$ and $50 \%$ of the diets in terms of weight. The reason sprat consumption by cod was so low in the 1977-1982 period was because of the very low sprat biomass in the Baltic at the time. The spawning stock of sprat in the Baltic then was approximately $250000 \mathrm{t}$, while the estimate for the 2006-2007 was approximately $900000 \mathrm{t}$ (Anonymous 2012). In turn, the herring biomass in the central Baltic was in 2006-2007 approximately half of its size in the late 1970s and early 1980s. In the 1950s, the primary food of cod were also clupeids, which comprised between $54 \%$ and $78 \%$ of the stomach contents, and the dominant among clupeids, as in the 1970s, was herring (Strzyżewska 1962).

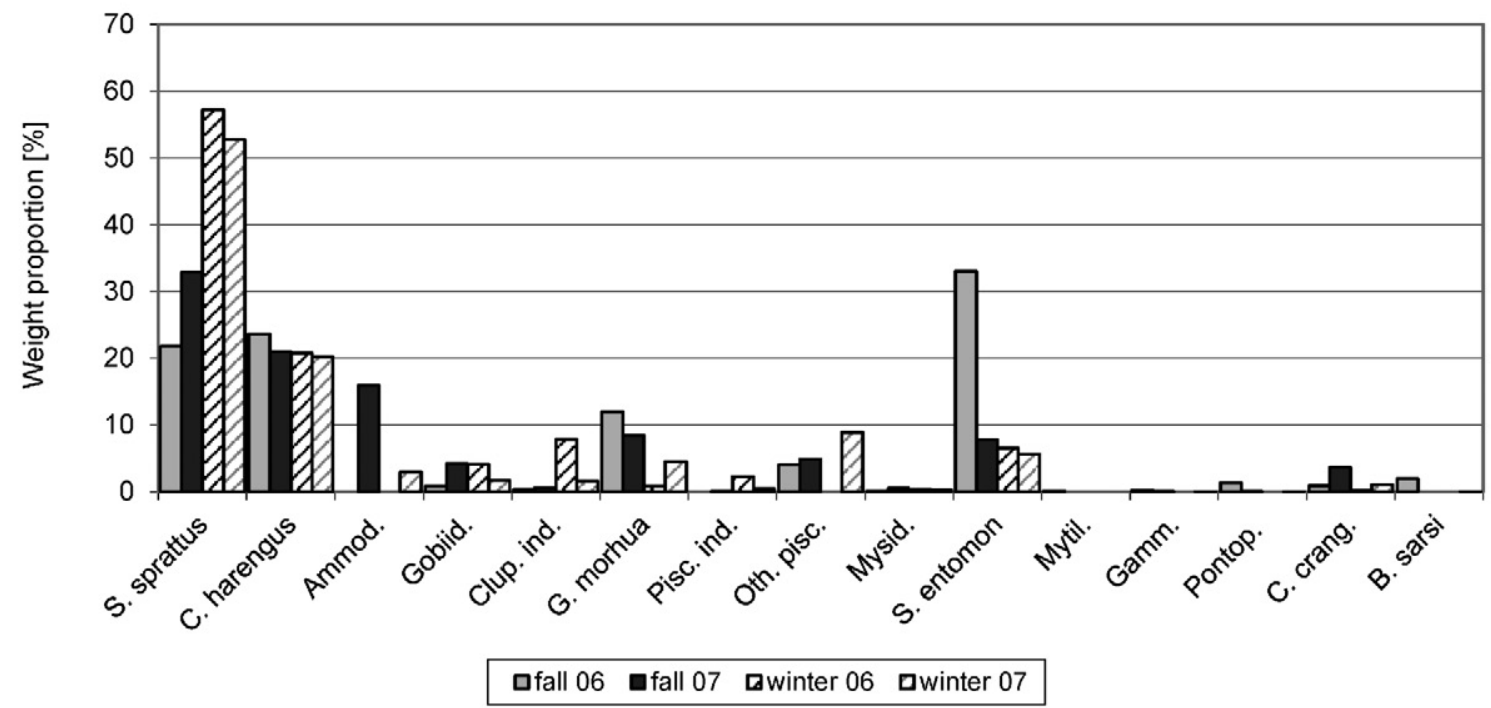

Fig. 6. Food composition of cod, Gadus morhua, by season for $\operatorname{cod}<80 \mathrm{~cm}$ in length; Ammod. = Ammodytidae, Gobiid. = Gobiidae, Clup. ind. = Clupeidae gen. spp., Pisc. ind. = Actinopterygii gen. spp., Oth. pisc. = Other fishes (identified), Mysid. = Mysidacea gen. spp., Mytil. = Mytilus sp., Gamm. = Gammarus sp., Pontop. = Pontoporeia sp., C. crang. = Crangon crangon, B. sarsi $=$ Bylgides sarsi, N. divers. $=$ Nereis diversicolor

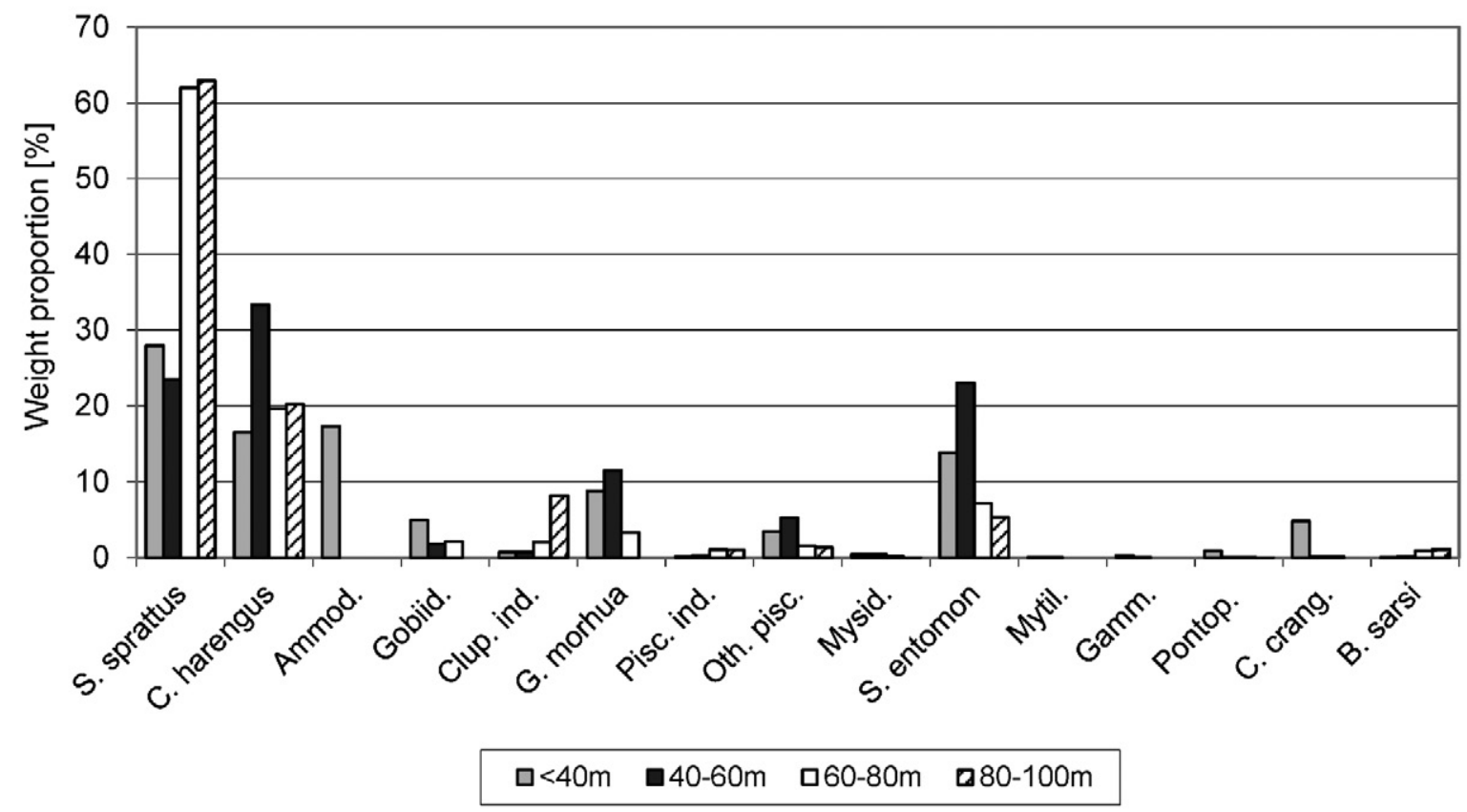

Fig. 7. Food composition of cod, Gadus morhua, in relation to depth in 2006 and 2007 for cod $<80 \mathrm{~cm}$; Ammod. = Ammodytidae, Gobiid. = Gobiidae, Clup. ind. = Clupeidae gen. spp., Pisc. ind. = Actinopterygii gen. spp., Oth. pisc. = Other fishes (identified), Mysid. = Mysidacea gen. spp., Mytil. = Mytilus sp., Gamm. = Gammarus sp., Pontop. = Pontoporeia sp., C. crang. = Crangon crangon, B. sarsi $=$ Bylgides sarsi, N. divers. $=$ Nereis diversicolor 
The proportion by weight of cod in the stomachs of adult cod calculated by Załachowski (1985) was similar to that observed in the presently reported study. The biomass of cod in the environment during that time period was several times higher than it is now, but this was not reflected in the greater consumption of juvenile cod by adult cod. The low proportion of sprat in the study by Załachowski (1985) was compensated by the higher proportion of invertebrates consumed, especially of Saduria entomon, Bylgides sarsi, and Mysidacea. The proportion of $S$. entomon was two times higher, while that of Bylgides sarsi was more than fifteen-fold higher. The presently reported study noted a high proportion of Gobiidae in the diet of $\operatorname{cod}(5 \%)$, while that observed by Załachowski (1985) was approximately $1 \%$.
The incidence of cannibalism, which was observed in all seasons, was 5\% (frequency of occurrence). According to Uzars (2000), the average frequency of cod occurrence in stomachs in subdivisions 26 and 28 within 1963-1990 was much lower (about 1\%). Cannibalism was noted more often in the winter than in the fall, but in the winter, the prey were mostly the youngest cod. Uzars (2000) reported that the cod consumed in the winter (Nov-Jan) and early spring (Mar-Apr) were mostly from the 0 and 1 age groups $(5-15 \mathrm{~cm})$. According to the above-mentioned author, the higher rate of cannibalism was associated with the greater abundance of juvenile cod. The stomachs of large fish, over $60 \mathrm{~cm}$ in length, often contained larger cod in excess of $20 \mathrm{~cm}$. In the late 1980s, Załachowski (1986)
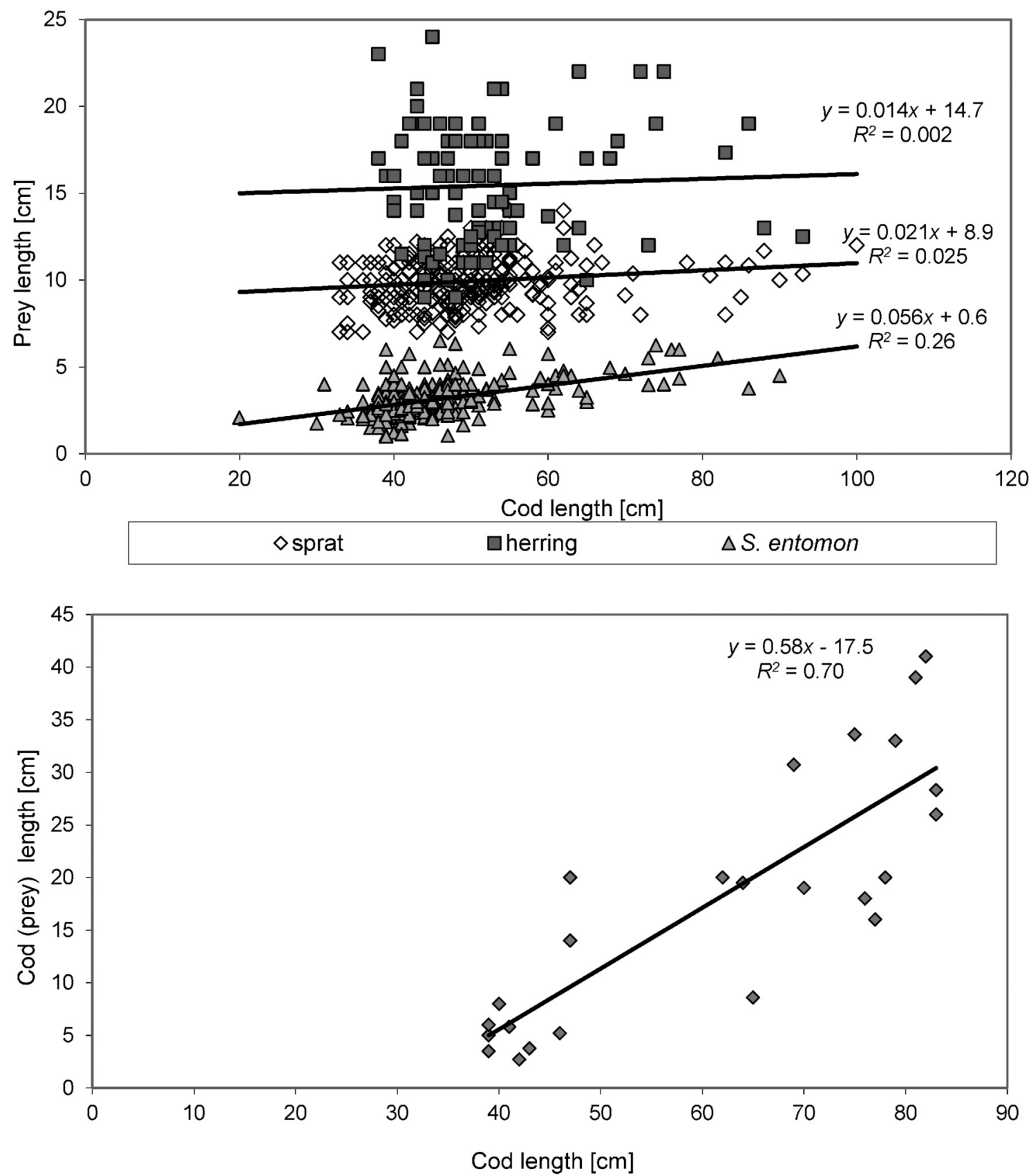

Fig. 8. Relation between mean prey length and cod, Gadus morhua, length for its food items: sprat, herring, Saduria entomon, and cod 
observed that in the years when clupeid consumption was lower, the sampled cod exhibited higher rates of cannibalism.

The type of food consumed by cod depends on their size. The presently reported study confirmed that as cod length increased, the proportion of the diet by weight that was made up of small and medium-sized fish (sprats, gobies) decreased, while the proportion of larger fish, such as herring and cod, increased systematically. These results concur with those reported by Załachowski (1977), who found that small fish species exhibited a consistent decreasing proportion by weight in the diet as cod length increased, and that the highest proportion of fish species of medium size (Ammodytidae, sprat) were noted in medium-sized cod. With the largest species, such as herring and cod, there was an increase in their proportion by weight in cod diets as predator length increased. Chrzan (1962) also stated an increasing proportion of herring in the food that corresponded to increases in cod size. Załachowski (1985) observed a large proportion of fourbeard rockling and cod in the diets of cod beginning at age 6 (i.e., at lengths of 50-60 cm). These components can comprise as much as $50 \%$ of all the fish consumed.

In the case of invertebrates, the number of species in the food of cod decreased with increasing length, which was also observed by Cięgielewicz et al. (1972). According to Załachowski (1977), the consumption of Saduria entomon increases with length for cod up to $45 \mathrm{~cm}$, and decreases for larger cod. In the presently reported study, a similar tendency was observed in 2007. In 2006, this trend was not observed, but the weight proportion of $S$. entomon was relatively high (Fig. 4). Small invertebrates were consumed less frequently as the length of the predator increased, which is in agreement with the results of Załachowski (1977). Neuenfeldt and Beyer (2003) showed a relation between cod length and the proportion of sprat, herring, and S. entomon in cod's diets. This finding was similar to our findings for samples collected from demersal hauls. Also our finding of size selection of $S$. entomon is similar to observation of Chrzan (1962), who stated that bigger cod consumed bigger $S$. entomon.

The higher proportion of sprat in cod food in Subdivision 26 compared to Subdivision 25 (Table 2) was consistent with sprat distribution, measured by the proportion of sprat catches in both subdivisions (Anonymous 2012).

In the fall, a high frequency of Saduria entomon (over $60 \%$ ) was observed in the stomachs of cod, similar to that of Cięgielewicz et al. (1972) and Uzars et al. (2000). S. entomon is a significant component of the adult cod diet and even reached $30 \%$ of the diet by weight. Fishes of the family Ammodytidae represented the highest individual share of the cod diet in the fall of 2007 (approximately $15 \%$ ). These results concur with the results obtained by Cięgielewicz et al. (1972) and Załachowski (1977), who noted more Ammodytidae in the food during the fall season.

The cod diet changed with the depth of the feeding grounds. Generally, as depth increased, so did the proportion of sprat in the diet, while the proportion of herring in the diet decreased. These trends were also observed by Załachowski et al. (1975). Gobiidae and Ammodytidae were consumed less frequently as depth increased, as was also noted by Załachowski (1977). The invertebrate composition varied as the depth of the feeding grounds increased. At depths greater than $40 \mathrm{~m}$, the proportions (weight percent) of Saduria entomon, Mysidacea, Gammarus sp., and Crangon crangon in cod stomachs all decreased. The same variations were also observed by Załachowski (1977). The observations of Chrzan (1962) indicated that the frequency of Crangon crangon consumption was four times higher in the coastal zone waters than at greater depths.

\section{REFERENCES}

Alheit J., Möllmann C., Dutz J., Kornilovs G., Loewe P., Mohrholz V., Wasmund N. 2005. Synchronous ecological regime shifts in the central Baltic and the North Sea in the late 1980s. ICES Journal of Marine Science 62 (7): 1205-1215. DOI: 10.1016/j.icesjms.2005.04.024

Anonymous 2012. Report of the Baltic fisheries assessment working group (WGBFAS). 12-19 April 2012, ICES Headquarters, Copenhagen. ICES CM 2012/ACOM: 10.

Arntz W.E. 1977. The food of adult cod (Gadus morhua L.) in the western Baltic. Meeresforschung 26: 60-69.

Chrzan F. 1962. Pokarm i odżywianie się dorsza w Zatoce Gdańskiej. [The food and feeding of cod in the Gulf of Gdańsk.] Prace MIR, seria A 11: 161-199. [In Polish, with English summary.]

Cięgielewicz W., Załachowski W., Szypuła J., Krzykawski S., Krzykawska I. 1972. Odżywianie się ryb przemysłowych południowego Bałtyku. [Feeding of commercial fishes of the southern Baltic.] Ekosystemy morskie 2: 363-450 [In Polish.]

Costello M. J. 1990. Predator feeding strategy and prey importance: a new graphical analysis. Journal of Fish Biology 36 (2): 261-263. DOI: 10.1111/j.1095-8649.1990.tb05601.x

Härkönen T.J. 1986. Guide to the otoliths of the bony fishes of the northeastern Atlantic. Danbiu ApS, Hellerup, Denmark.

Helgason T., Gislason H. 1979. VPA analysis with species interactions due to predation. International Council for the Exploration of the Sea, Demersal Fish Committee, G:52.

Horbowy J. 1996. The dynamics of Baltic fish stocks on the basis of a multispecies stock-production model. Canadian Journal of Fisheries and Aquatic Sciences 53 (9): 2115-2125. DOI: 10.1139/f96-128

Nelder J.A., Wedderburn R.W.M. 1972. Generalized linear models. Journal of the Royal Statistical Society, Series A (General) 135 (3): 370-384.

Neuenfeldt S., Beyer J.E. 2003. Oxygen and salinity characteristics of predator-prey distributional overlaps shown by predatory Baltic cod during spawning. Journal of Fish Biology 62 (1): 168-183. DOI: 10.1046/j.10958649.2003.00013.x

Neuenfeldt S., Beyer J.E. 2006. Environmentally driven predator-prey overlaps determine the aggregate diet of the cod Gadus morhua in the Baltic Sea. Marine Ecology Progress Series 310: 151-163. DOI: 10.3354/meps310151 
Reimann Z. 1955. Odżywianie się i pokarm młodocianego dorsza (Gadus callarias) południowego Bałtyku. [Nutrition and food of young cod (Gadus callarias) of the southern Baltic.] Prace MIR 8: 171-186. [In Polish, with English summary.]

Strzyżewska K. 1959. Odżywianie się i pokarm dorsza bałtyckiego. [Nutrition and food of Baltic cod.] Pp. 45-59. In: Mańkowski W. (ed.) Dorsz bałtycki: jego połowy i technologia. [Balitic cod: ts catches and processing technology.] Gdańskie Towarzystwo Naukowe, Gdańsk, Poland. [In Polish.]

Strzyżewska K. 1962. Odżywianie się i pokarm dorsza Bałtyku Południowego. [Nourishment and food of southern Baltic cod]. Prace MIR, seria A 11: 387-419. [In Polish, with English summary.]

Uzars D. 1985. Food composition in the Eastern Baltic cod for the 1963-1984 period. ICES CM 1985/J3.

Uzars D., Baranova T., Yula E. 2000. Variation in environmental conditions, feeding and growth of cod in the Eastern Baltic. ICES CM 2000/Q10.

Uzars D., Plikshs M. 2000. Cod (Gadus morhua L.) cannibalism in the Central Baltic: interannual variability and influence of recruit abundance and distribution. ICES Journal of Marine Science 57 (2): 324-329. DOI: 10.1006/ jmsc. 1999.0527

Załachowski W., Szypuła J., Krzykawski S., Krzykawska I. 1975. Feeding of some commercial fishes in the Southern
Region of Baltic Sea - in 1971 and 1972. PolskieArchiwum Hydrobiologii 22 (3): 429-448.

Załachowski W. 1977. Ilościowa i ekologiczna analiza pokarmu użytkowanego przez populację dorsza w południowym Bałtyku w latach 1972-1974. [Quantitative and ecological analysis of food consumed by southern Baltic cod population in the years 1972-1974.] Rozprawy, Akademia Rolnicza w Szczecinie, Szczecin, Poland No. 53: 1-109. [In Polish, with English summary.]

Zalachowski W. 1985. Amount and composition of food of cod (Gadus morhua) in the southern Baltic in 1977-1982. Acta Ichthyologica et Piscatoria 15 (2): 95-118.

Zalachowski W. 1986. An attempt to estimate food biomass eliminated annually by the cod (Gadus morhua L.) population in the Baltic, based on studies in 1977-1982. Acta Ichthyologica et Piscatoria 16 (1): 3-23.

Załachowski W. 1992. Odżywianie się dorsza (Gadus morhua) w południowym Bałtyku w latach 1986-1989. [Feeding of cod in the southern Baltic within 1986-1989.] Zeszyty Naukowe Akademii Rolniczej w Szczecinie 19 (150): 59-66. [In Polish, with English summary.]

Received: 31 October 2012 Accepted: 26 April 2013 Published electronically: 30 June 2013 